\title{
Sorbicillinoid analogs with cytotoxic and selective anti-Aspergillus activities from Scytalidium album
}

\author{
Tamam El-Elimat ${ }^{1}$, Huzefa A Raja ${ }^{1}$, Mario Figueroa ${ }^{1}$, Steven M Swanson ${ }^{2}$, Joseph O Falkinham III $^{3}$, \\ David M Lucas ${ }^{4,5}$, Michael R Grever ${ }^{4}$, Mansukh C Wani ${ }^{6}$, Cedric J Pearce ${ }^{7}$ and Nicholas H Oberlies ${ }^{1}$
}

As part of an ongoing project to explore filamentous fungi for anticancer and antibiotic leads, 11 compounds were isolated and identified from an organic extract of the fungus Scytalidium album (MSX51631) using bioactivity-directed fractionation against human cancer cell lines. Of these, eight compounds were a series of sorbicillinoid analogs (1-8), of which four were new (scalbucillin A (2), scalbucillin B (3), scalbucillin C (6) and scalbucillin D (8)), two were phthalides (9-10) and one was naphthalenone (11). Compounds (1-11) were tested in the MDA-MB-435 (melanoma) and SW-620 (colon) cancer cell lines. Compound 1 was the most potent with $\mathrm{IC}_{50}$ values of 1.5 and $0.5 \mu \mathrm{M}$, followed by compound 5 with IC $\mathrm{C}_{50}$ values of 2.3 and $2.5 \mu \mathrm{M}$ at $72 \mathrm{~h}$. Compound 1 showed a $48-\mathrm{h} \mathrm{IC}_{50}$ value of $3.1 \mu \mathrm{m}$ when tested against the lymphocytic leukemia cell line OSU-CLL, while the nearly identical compound 5 had almost no activity in this assay. Compounds 1 and 5 showed selective and equipotent activity against Aspergillus niger with minimum IC values of 0.05 and $0.04 \mu \mathrm{g} \mathrm{ml} \mathrm{m}^{-1}(0.20$ and $0.16 \mu \mathrm{m})$, respectively. The in vitro hemolytic activity against sheep erythrocytes of compounds 1 and 5 was investigated and were found to provoke $10 \%$ hemolysis at 52.5 and $45.0 \mu \mathrm{g} \mathrm{ml}^{-1}$, respectively, indicative of a promising safety factor.

The Journal of Antibiotics (2015) 68, 191-196; doi:10.1038/ja.2014.125; published online 24 September 2014

\section{INTRODUCTION}

Bioactivity-directed purification studies of filamentous fungi from the Mycosynthetix library, representing over 55000 accessions, have yielded structurally diverse cytotoxic secondary metabolites. ${ }^{1-6}$ As part of these, the organic extract of a solid-phase culture of a fungus identified as Scytalidium album (MSX51631), which was isolated in 1990 from Cobb County, GA, USA, showed promising cytotoxic activities against the SW-620 (colon) and MDA-MB-435 (melanoma) cancer cell lines. Bioactivity-directed fractionation resulted in the isolation and identification of eight sorbicillinoid analogs (1-8), of which four were new (scalbucillin A (2), scalbucillin B (3), scalbucillin $\mathrm{C}(\mathbf{6})$ and scalbucillin $\mathrm{D}(\mathbf{8})$ ) and four were known (5'-formyl-2'-hydroxyl-4'-methoxy- $(E, E)$-sorbophenone (1), 1-(2'hydroxy-4'-methoxy-5'-methylphenyl)-2,4-E,E-hexadien-1-one (4), 5 -formyl-2'-hydroxy-4'-methoxy-(E)-4-hexenophenone (5) and 1-(2'-hydroxy-4'-methoxy-5'-hydroxymethylphenyl)-E-4-hexen-1-one (7)). Also, two phthalides (5,7-dimethoxyphthalide (9) and 4,6dimethoxyphthalide (10)) and one naphthalenone (isosclerone (11)) were isolated. Compounds 1-11 were evaluated for cytotoxicity against human cancer cell lines, and compounds $\mathbf{1}$ and $\mathbf{5}$ were further evaluated for growth inhibitory activity against a B-lymphocytic leukemia cell line, OSU-CLL. ${ }^{7}$ The antimicrobial activities of all isolates were also evaluated in an array of bacteria and fungi. The hemolytic activity of compounds $\mathbf{1}, \mathbf{3}$ and $\mathbf{5}$ was measured against sheep red blood cells, so as to probe a safety factor with respect to the promising anti-Aspergillus activity of these three compounds.

\section{RESULTS AND DISCUSSION}

Two solid-substrate large-scale cultures of the fungus S. album were extracted with $1: 1 \mathrm{CHCl}_{3}-\mathrm{MeOH}$ and partitioned with water. The vacuum-dried organic extract was then defatted with $1: 1 \mathrm{CH}_{3} \mathrm{CN} /$ $\mathrm{MeOH}$-hexane. The resulting $\mathrm{CH}_{3} \mathrm{CN} / \mathrm{MeOH}$-soluble extract showed cytotoxic activity against the SW-620 and MDA-MB-435 cancer cell lines $(\sim 83 \%$ and $71 \%$ inhibition of cell growth when tested at $20 \mu \mathrm{g} \mathrm{ml}^{-1}$, respectively), and was subjected to fractionation using flash chromatography. Active fractions were purified using reversedphase preparative and semipreparative HPLC to yield compounds 1-11 with $>95 \%$ purity as evidenced by UPLC (Supplementary Figure S1).

A series of eight sorbicillinoid analogs (1-8), of which four were new, all possessing the carbon skeleton of the known antibiotic, sorbicillin, ${ }^{8}$ were isolated and identified in this study (Figure 1). The NMR, HR-MS and UV data identified $\mathbf{1}(13.87 \mathrm{mg})$ and $\mathbf{5}(3.25 \mathrm{mg})$ as the known $5^{\prime}$-formyl-2'-hydroxyl-4'-methoxy-(E,E)-sorbophenone

\footnotetext{
${ }^{1}$ Department of Chemistry and Biochemistry, University of North Carolina at Greensboro, Greensboro, NC, USA; ${ }^{2}$ Department of Medicinal Chemistry and Pharmacognosy, University of Illinois at Chicago, Chicago, IL, USA; ${ }^{3}$ Department of Biological Sciences, Virginia Polytechnic Institute and State University, Blacksburg, VA, USA; ${ }^{4}$ Division of Hematology, College of Medicine, The Ohio State University, Columbus, OH, USA; ${ }^{5}$ Division of Medicinal Chemistry and Pharmacognosy, College of Pharmacy, The Ohio State University, Columbus, $\mathrm{OH}$, USA; ${ }^{6}$ Natural Products Laboratory, Research Triangle Institute, Research Triangle Park, NC, USA and ${ }^{7}$ Mycosynthetix Inc., Hillsborough, NC, USA Correspondence: Dr NH Oberlies, Department of Chemistry and Biochemistry, University of North Carolina at Greensboro, 435 Sullivan Sciences Building, Greensboro, NC 27402, USA. 
<smiles>[R]c1cc(C(=O)/C=C/C=C/C)c(O)cc1OC</smiles><smiles>[R]c1cc(C(=O)CC/C=C/C)c(O)cc1OC</smiles><smiles>COc1cc2c(c(OC)c1)C(=O)OC2</smiles>

9<smiles>COc1cc(OC)c2c(c1)C(=O)OC2</smiles>

10<smiles>O=C1CC[C@H](O)c2cccc(O)c21</smiles>

11

Figure 1 Structure of compounds (1-11) isolated from S. album.

and $5^{\prime}$-formyl-2'-hydroxy-4'-methoxy-(E)-4-hexenophenone, respectively. Both of these were isolated in 1973 from the fungus Scytalidium sp. FY strain. ${ }^{9}$ In an analogous manner, compounds $4(5.89 \mathrm{mg})$ and $7(8.21 \mathrm{mg})$ were identified as the known 1-(2'-hydroxy- $4^{\prime}$-methoxy$5^{\prime}$-methylphenyl)- E,E-2,4-hexadien-1-one and 1-(2'-hydroxy-4'methoxy-5'-hydroxymethylphenyl)-E-4-hexen-1-one, respectively. Both compounds 4 and 7 were isolated in 2006 from a fungicolous isolate of the genus Phaeoacremonium. ${ }^{10}$ Characterization data for these known isolates compared favorably with the literature (see Supplementary Figure S2 for ${ }^{1} \mathrm{H}$ and ${ }^{13} \mathrm{C}$ NMR spectra of compounds 1, 4, 5 and 7 , respectively).

Four new sorbicillinoid analogs (2, 3, 6 and 8) were isolated as well, and their structures were identified by comparison of HR-MS and NMR data with each other and with structurally related known compounds. Compound $2(1.77 \mathrm{mg})$ was obtained as a yellow powder. The molecular formula was determined as $\mathrm{C}_{14} \mathrm{H}_{14} \mathrm{O}_{5}$ via HR-ESIMS along with ${ }^{1} \mathrm{H},{ }^{13} \mathrm{C}$ and edited-HSQC NMR data (Tables 1 and 2; Supplementary Figure S3), establishing an index of hydrogen deficiency of 8. Inspection of the HR-MS and NMR data suggested 2 as a sorbicillinoid analog with structural similarity with 1 . For example, compound 2 showed the characteristic $\mathrm{C1}^{\prime}-\mathrm{C6}^{\prime}$ sorbyl side chain, as noted by two conjugated double bonds with coupling constants consistent with an $E, E$ configuration $\left(J_{\mathrm{H}-2 / \mathrm{H}-3}\right.$ and $\left.J_{\mathrm{H}-4 / \mathrm{H}-5}=14.6 \mathrm{~Hz}\right)$ that were conjugated with a ketone carbonyl $\left(\delta_{\mathrm{C}} 192.8\right)$ that was further conjugated with an aryl group. Additional similarities included NMR signals characteristic of six aromatic carbons and two singlet aromatic protons, suggesting a 1,2,4,5-tetrasubstituted benzene ring with two aromatic protons para to each other, a methoxy group and a hydrogen-bonded phenolic proton. All of the benzene ring substituents were confirmed by HMBC correlations (Figure 2). Key differences between compounds 1 and 2 were the replacement of the singlet aldehyde proton and the carbonyl carbon in $1\left(\delta_{\mathrm{H}} / \delta_{\mathrm{C}}\right.$ $10.27 / 187.7)$ by a broad exchangeable proton and a carboxylic acid carbon in $2\left(\delta_{\mathrm{H}} / \delta_{\mathrm{C}} 10.05 / 164.3\right)$. These data, along with an extra oxygen atom in 2 relative to 1 , as supported by a 16 a.m.u. difference in the HR-MS data, suggested that the aldehyde substituent at C-5' of the benzene ring in $\mathbf{1}$ was replaced by a carboxylic acid group in $\mathbf{2}$. The trivial name scalbucillin A was ascribed to 2 .

Compound $3(1.10 \mathrm{mg})$ was obtained as a yellow powder with a molecular formula of $\mathrm{C}_{14} \mathrm{H}_{16} \mathrm{O}_{4}$ as determined by HR-ESIMS and analysis of ${ }^{1} \mathrm{H}$ NMR, ${ }^{13} \mathrm{C}$ NMR and edited-HSQC NMR data

(Tables 1 and 2; Supplementary Figure S4). Inspection of the NMR data suggested compound $\mathbf{3}$ as a sorbicillinoid analog with structural similarity to 7. However, compound 3 lacked the four aliphatic protons $\mathrm{H}_{2}-2$ and $\mathrm{H}_{2}-3\left(\delta_{\mathrm{H}} 2.98\right.$ and 2.41) that were replaced by two olefinic protons $\left(\delta_{\mathrm{H}} 6.95\right.$ and 7.49$)$ with a coupling constant consistent with an $E$ configuration $\left(J_{\mathrm{H}-2 / \mathrm{H}-3}=15.0 \mathrm{~Hz}\right)$. Conjugation of the C2-C3 double bond with the ketone carbonyl resulted in an upfield shift of the chemical shift of $\mathrm{C} 1$ in 3 relative to 7 . Further examination of the NMR data, including COSY and HMBC spectra (Figure 2), yielded the structure of $\mathbf{3}$, which was ascribed the trivial name scalbucillin B.

Compound $6(9.97 \mathrm{mg})$ was obtained as a white powder. The chemical formula was determined as $\mathrm{C}_{15} \mathrm{H}_{18} \mathrm{O}_{5}$ by HR-ESIMS and analysis of ${ }^{1} \mathrm{H},{ }^{13} \mathrm{C}$ and edited-HSQC NMR data (Tables 1 and 2; Supplementary Figure S7). Examining the NMR data suggested a sorbicillinoid analog with structural similarity to $\mathbf{5}$ (Table 1 ). As in $\mathbf{5}$, compound 6 showed NMR signals consistent with a side chain containing two olefinic protons with a coupling constant that supported an $E$ configuration $\left(J_{\mathrm{H}-4 / \mathrm{H}-5}=15.5 \mathrm{~Hz}\right)$. A chemical shift of the ketone carbonyl of 204.7 p.p.m. indicated the lack of conjugation with the double bond. Furthermore, the presence of a threeproton doublet of doublets $\left(\delta_{\mathrm{H}-6} 1.65, \mathrm{dd}, J=6.3,1.2 \mathrm{~Hz}\right)$ with a chemical shift and coupling constants consistent with an allylic position established the side chain of compound 6 (Figure 1). Additional similarities included NMR data characteristic of a 1,2,4,5tetrasubstituted benzene ring with two sharp singlet aromatic protons, indicating positions para to each other. A sharp singlet proton $\left(\delta_{\mathrm{H}}\right.$ 13.05), which did not show single-bond coupling to a carbon as evidenced from the edited-HSQC NMR experiment, indicated a phenolic proton ortho to the side chain and hydrogen bonded with the carbonyl carbon. Key differences between compounds 5 and $\mathbf{6}$ include replacement of the aldehyde proton in $5\left(\delta_{\mathrm{H}} 10.26\right)$ by a methoxy functionality in $6\left(\delta_{\mathrm{H}} / \delta_{\mathrm{C}} 3.88 / 52.2\right)$ and replacement of the aldehyde carbon $\left(\delta_{\mathrm{C}} 187.5\right)$ by an ester functionality $\left(\delta_{\mathrm{C}} 165.4\right)$. These data, along with a 30 a.m.u. difference in the HR-MS data of compounds 5 and $\mathbf{6}$, indicated replacement of the aldehyde in 5 by a methyl ester in $\mathbf{6}$. The trivial name scalbucillin $\mathrm{C}$ was ascribed to compound 6.

Compound 8 (2.47 $\mathrm{mg})$, which was obtained as a white powder, had a molecular formula of $\mathrm{C}_{14} \mathrm{H}_{18} \mathrm{O}_{3}$ as determined by HR-ESIMS and analysis of ${ }^{1} \mathrm{H},{ }^{13} \mathrm{C}$ and edited-HSQC NMR data (Tables 1 and 2; Supplementary Figure S9). The NMR data of $\mathbf{8}$ indicated a sorbicillinoid analog with structural similarity to 4 . However, 8 lacked the $\mathrm{H}-2$ and $\mathrm{H}-3$ olefinic protons, which were replaced by four aliphatic protons $\left(\delta_{\mathrm{H}} 2.95\right.$ and 2.40 for $\mathrm{H}_{2}-2$ and $\mathrm{H}_{2}-3$, respectively). This resulted in a downfield shift of $\mathrm{C} 1$ in $8\left(\delta_{\mathrm{C}} 204.2\right)$, relative to that in 4 $\left(\delta_{\mathrm{C}}\right.$ 192.3), as the latter conjugates with the C2-C3 double bond. Further analysis of the NMR data, including COSY and HMBC experiments (Figure 2), yielded the structure of $\mathbf{8}$, which was ascribed the trivial name scalbucillin $\mathrm{D}$.

In addition to compounds $\mathbf{1 - 8}$, two known phthalides (5,7dimethoxyphthalide $(\mathbf{9})^{11,12}$ and 4,6-dimethoxyphthalide $(\mathbf{1 0})^{13,14}$ ) and one known naphthalenone (isosclerone $(\mathbf{1 1}))^{15}$ were isolated and identified by comparison of NMR, HR-MS and optical rotation data (for 11) with the literature. This is the first report of $\mathbf{1 0}$ from a fungal source.

The cytotoxicity of compounds (1-11) was measured against MDAMB-435 and SW-620 cancer cell lines. Compound 1 was the most potent with $\mathrm{IC}_{50}$ values (concentrations that inhibit growth by $50 \%$ relative to untreated cells) of 1.5 and $0.5 \mu \mathrm{M}$, respectively, followed by compound 5 , with $\mathrm{IC}_{50}$ values of 2.3 and $2.5 \mu \mathrm{M}$, respectively 
Table $1{ }^{1} \mathrm{H}$ NMR data for compounds 2, 3, 6 and 8 (in $\mathrm{CDCl}_{3}$, $700 \mathrm{MHz}$ for 2 and 3 and $500 \mathrm{MHz}$ for 6 and 8 , chemical shifts in p.p.m., coupling constants in $\mathrm{Hz}$ )

\begin{tabular}{|c|c|c|c|c|}
\hline & 2 & 3 & 6 & 8 \\
\hline Position & $\begin{array}{l}\delta_{H}, \text { Mult. } \\
(\mathrm{J} \text { in } \mathrm{Hz})\end{array}$ & $\begin{array}{l}\delta_{H}, \text { Mult. } \\
(\mathrm{J} \text { in } \mathrm{Hz})\end{array}$ & $\begin{array}{l}\delta_{H}, \text { Mult. } \\
(\mathrm{J} \text { in } \mathrm{Hz})\end{array}$ & $\begin{array}{l}\delta_{H}, \text { Mult. } \\
(\mathrm{J} \text { in } \mathrm{Hz})\end{array}$ \\
\hline 1 & - & - & - & - \\
\hline 2 & $7.05, d(14.6)$ & $6.95, d(15.0)$ & $\begin{array}{c}3.02 \text {, dd }(7.5 \\
6.9)\end{array}$ & $\begin{array}{c}2.95, \mathrm{dd}(8.0 \\
7.5)\end{array}$ \\
\hline 3 & $\begin{array}{c}7.54, \mathrm{dd} \\
(14.6,9.9)\end{array}$ & $\begin{array}{c}7.49, \mathrm{dd}(15.0 \\
10.6)\end{array}$ & $\begin{array}{c}2.41, \text { ddd }(7.5 \\
6.9,6.3)\end{array}$ & $\begin{array}{c}2.40 \text {, ddd }(8.0, \\
7.5,5.2)\end{array}$ \\
\hline 4 & $6.39, \mathrm{~m}$ & $6.34, \mathrm{~m}$ & $\begin{array}{c}5.49, \text { dtq }(15.5 \\
6.3,1.2)\end{array}$ & $\begin{array}{c}5.49 \text {, dtq }(15.5, \\
5.2,0.6)\end{array}$ \\
\hline 5 & $\begin{array}{c}6.38, d q \\
(14.6,5.1)\end{array}$ & $\begin{array}{c}\text { 6.31, dq (15.0 } \\
6.4)\end{array}$ & $\begin{array}{c}5.50, \mathrm{dq}(15.5 \\
6.3)\end{array}$ & $\begin{array}{c}5.50, \mathrm{dq}(15.5, \\
5.2)\end{array}$ \\
\hline 6 & $1.94, d(5.1)$ & $\begin{array}{c}1.92, \mathrm{dd}(6.4 \\
0.6)\end{array}$ & $\begin{array}{c}1.65, \text { dd }(6.3, \\
1.2)\end{array}$ & $\begin{array}{c}1.65, \mathrm{dd}(5.2 \\
0.6)\end{array}$ \\
\hline $1^{\prime}$ & - & - & - & - \\
\hline $2^{\prime}$ & - & - & - & - \\
\hline $3^{\prime}$ & $6.58, \mathrm{~s}$ & $6.46, \mathrm{~s}$ & $6.47, \mathrm{~s}$ & $6.37, \mathrm{~s}$ \\
\hline $4^{\prime}$ & - & - & - & - \\
\hline $5^{\prime}$ & - & - & - & - \\
\hline $6^{\prime}$ & $8.74, \mathrm{~s}$ & $7.71, \mathrm{~s}$ & $8.37, \mathrm{~s}$ & $7.44, \mathrm{~s}$ \\
\hline $7^{\prime}$ & - & $4.64, d(6.1)$ & - & - \\
\hline $8^{\prime}$ & $4.12, \mathrm{~s}$ & $3.90, \mathrm{~s}$ & $3.88, \mathrm{~s}$ & $3.84, \mathrm{~s}$ \\
\hline $9^{\prime}$ & - & - & $3.93, \mathrm{~s}$ & - \\
\hline $2^{\prime}-\mathrm{OH}$ & $13.87, \mathrm{~s}$ & $13.58, \mathrm{~s}$ & $13.05, \mathrm{~s}$ & $12.79, \mathrm{~s}$ \\
\hline $7^{\prime}-\mathrm{OH}$ & 10.05, bs & $2.02, \mathrm{t}(6.1)$ & - & - \\
\hline
\end{tabular}

Abbreviation: Mult., multiplicity.

(Table 3). Testing of closely related analogs permitted preliminary conclusions regarding structure-activity relationships, particularly the importance of the aldehyde group at $5^{\prime}$. Replacing the aldehyde with a carboxylic acid rendered the compounds inactive as in 2 . A second important structural feature was the requirement of the intact sorbyl side chain for biological activity. Compound 5, with a reduced C2-C3 double bond, was less active by 1.5- and 5-fold in comparison with 1 when measured against the MDA-MB-435 and SW-620 cancer cell lines, respectively. This latter observation was supported by moderate growth inhibitory activity with compounds 3 and $\mathbf{4}$ that was not present in compounds $\mathbf{7}$ and $\mathbf{8}$, which differ only by reduction of the same double bond. Interestingly, compound 1 was similarly active against the B-lymphocytic leukemia cell line OSU-CLL as compared with the solid tumor cell lines (48-h $\mathrm{IC}_{50}$ of $\left.3.1 \mu \mathrm{M}\right)$, but compound 5 lacked significant activity in this context. Compound $\mathbf{1}$, which was isolated previously from the fungus $S$. album, ${ }^{9,16}$ displayed growth inhibitory activity when tested against $9 \mathrm{~KB}$ as reported by the National Cancer Institute (NSC 174259), with $\mathrm{ED}_{50}$ (dose that inhibits growth to $50 \%$ of the control growth by 3 days after addition of the drug) value of $0.3 \mu \mathrm{g} \mathrm{ml}^{-1} .{ }^{16}$ Neither the researchers' own activity data of compound 1 nor the National Cancer Institute data were published (personal communication with Dr David Newman, National Cancer Institute).

The antimicrobial activity of the isolated compounds (1-11) was evaluated against a panel of bacteria and fungi (Table 4 and Supplementary Table S1). Compounds $\mathbf{1}$ and $\mathbf{5}$ showed selective and equipotent activity against the filamentous fungus $A$. niger with MIC values of 0.05 and $0.04 \mu \mathrm{g} \mathrm{ml}^{-1}(0.20$ and $0.16 \mu \mathrm{M})$, respectively,
Table $2{ }^{13} \mathrm{C}$ NMR data for compounds 2, 3, 6 and 8 (in $\mathrm{CDCl}_{3}$, $175 \mathrm{MHz}$ for 2 and 3, and $125 \mathrm{MHz}$ for 6 and 8, chemical shifts in p.p.m.)

\begin{tabular}{|c|c|c|c|c|}
\hline & 2 & 3 & 6 & 8 \\
\hline Position & $\delta_{C}$ & $\delta_{C}$ & $\delta_{C}$ & $\delta_{C}$ \\
\hline 1 & 192.8 & 192.4 & 204.7 & 204.2 \\
\hline 2 & 120.6 & 121.4 & 38.0 & 38.0 \\
\hline 3 & 146.9 & 145.1 & 27.2 & 27.5 \\
\hline 4 & 130.4 & 130.4 & 129.2 & 129.6 \\
\hline 5 & 143.5 & 141.8 & 126.6 & 126.2 \\
\hline 6 & 19.1 & 19.0 & 18.0 & 18.0 \\
\hline $1^{\prime}$ & 115.1 & 113.3 & 112.9 & 112.7 \\
\hline $2^{\prime}$ & 169.6 & 166.5 & 167.9 & 164.0 \\
\hline $3^{\prime}$ & 100.5 & 99.7 & 100.5 & 99.0 \\
\hline $4^{\prime}$ & 163.1 & 163.8 & 165.5 & 164.3 \\
\hline $5^{\prime}$ & 109.2 & 120.7 & 111.6 & 118.1 \\
\hline $6^{\prime}$ & 137.2 & 129.9 & 135.9 & 131.1 \\
\hline $7^{\prime}$ & 164.3 & 61.2 & 165.4 & 15.8 \\
\hline $8^{\prime}$ & 57.2 & 55.8 & 52.2 & 55.8 \\
\hline $9^{\prime}$ & - & - & 56.5 & - \\
\hline
\end{tabular}

followed by compound 3 with an MIC value of $0.60 \mu \mathrm{g} \mathrm{ml}^{-1}$ $(2.42 \mu \mathrm{M})$. Relative to amphotericin $\mathrm{B}$, a clinically used agent that was used as a positive control, compounds $\mathbf{1}$ and $\mathbf{5}$ were more potent by more than two orders of magnitude. A hemolytic assay was used to assess the toxicity of compounds $\mathbf{1}, \mathbf{3}$ and $\mathbf{5}$ toward sheep red blood cells in vitro. Compounds 1, 3 and 5 resulted in 10\% hemolysis of sheep red blood cells at 52.5, 37.5 and $45.0 \mu \mathrm{g} \mathrm{ml}^{-1}$, respectively, with safety factors (calculated as the $10 \%$ hemolysis concentration over MIC) of 1050, 62.5 and 1125, respectively (Table 4). Antifungal activities in disk assays against $A$. flavus and Fusarium verticillioides of compounds 1 and 7 were reported previously by Reátegui et al. ${ }^{10}$ In the current study, compound 7 showed no activity against the tested fungal strains.

\section{CONCLUSIONS}

A series of eight sorbicillinoid analogs (1-8), of which four were new, along with two phthalides (9-10), and one naphthalenone (11), were isolated from the fungus S. album (MSX51631). Although the sorbicillinoid family encompasses over 50 members, only four sorbicillin-type phenolics, as described by Harned et al., ${ }^{8}$ have been isolated previously from natural sources. This study served to double that to eight related analogs; it is not clear, however, if these compounds are produced by the same biosynthetic route that leads to sorbicillin. ${ }^{8}$

This report expands significantly upon the structure-activity relationship of these compounds in cytotoxicity assays, establishing the importance of the aldehyde moiety at the $5^{\prime}$ position and the conjugated sorbyl side chain. Whether the aldehyde was oxidized to the carboxylic acid (such as compound 2) or reduced to the primary alcohol (such as compound 3 ), the growth inhibitory activity was diminished, suggesting the reaction of the aldehyde-containing compounds with DNA, RNA or proteins to form Schiff base adducts. ${ }^{17,18}$ Similarly, when the aldehyde was retained but the sorbyl side chain was reduced, as in compound $\mathbf{5}$ versus $\mathbf{1}$, the growth inhibitory activity was reduced by 1.5 - to 5 -fold in solid tumor cell lines, and at least 10-fold in a B-lymphocytic cell line ( $\mathrm{IC}_{50}$ of $\mathbf{5}$ not reached in those cells). This is in clear contrast to the activities of compounds $\mathbf{1}$ and $\mathbf{5}$ 


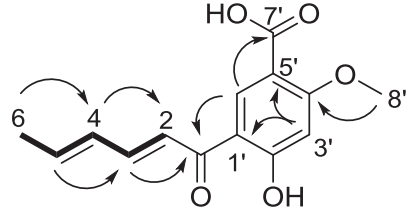

2

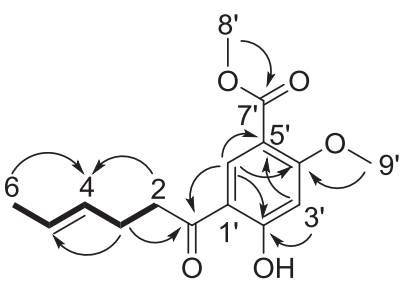

6

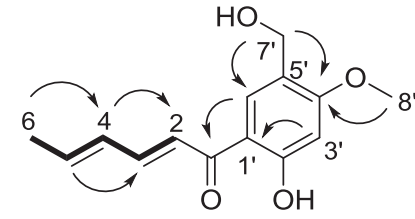

3

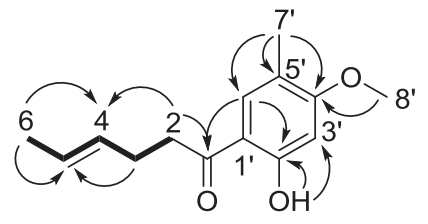

8
HMBC COSY

Figure 2 Key HMBC and COSY correlations of compounds 2, 3, 6 and 8 .

Table 3 Activity of compounds 1-11 against two human tumor cell lines

\begin{tabular}{lcc}
\hline & \multicolumn{2}{c}{ IC $_{50}$ values in $\mu \mathrm{M}^{\mathrm{b}}$} \\
\cline { 2 - 3 } Compounds $^{\mathrm{a}}$ & MDA-MB-435 & $S W-620^{c}$ \\
\hline $\mathbf{1}$ & 1.5 & 0.5 \\
$\mathbf{3}$ & 67.9 & 16.0 \\
$\mathbf{4}$ & 65.2 & 15.1 \\
$\mathbf{5}$ & 2.3 & 2.5 \\
\hline
\end{tabular}

aCompounds $\mathbf{2}$ and $\mathbf{6 - 1 1}$ were inactive.

b $\mathrm{C}_{50}$ values were determined as the concentration required to inhibit growth to $50 \%$ of control with a 72 -h incubation.

with a 72-h incubation.
cPositive control was vinblastine tested at concentration of $1 \mathrm{~nm}$ in MDA-MB-435 cells and

$10 \mathrm{~nm}$ in SW-620 cells, which had $48 \%$ and $30 \%$ viable cells, respectively.

Table 4 Antifungal and hemolytic activity of compounds 1,3 and 5

\begin{tabular}{|c|c|c|c|c|c|}
\hline \multirow[b]{2}{*}{ Compound } & \multicolumn{3}{|c|}{ Minimal IC $\left(\mu g m I^{-1}\right)$} & \multirow{2}{*}{$\begin{array}{c}10 \% \\
\text { Hemolysis } \\
\left(\mu g \mathrm{ml}^{-1}\right)^{\mathrm{a}}\end{array}$} & \multirow{2}{*}{$\begin{array}{l}\text { Safety } \\
\text { factor }^{b}\end{array}$} \\
\hline & C. albicans & C. neoformans & A. niger & & \\
\hline 1 & $>53$ & $>53$ & 0.05 & 52.5 & 1050 \\
\hline 3 & $>38$ & $>38$ & 0.60 & 37.5 & 62.5 \\
\hline 5 & $>45$ & $>45$ & 0.04 & 45.0 & 1125 \\
\hline Amphotericin $\mathrm{B}^{\mathrm{C}}$ & 16 & 8 & 31 & 62.5 & 2.0 \\
\hline Triton $\mathrm{X}-100^{c}$ & NT & NT & NT & 0.40 & NA \\
\hline
\end{tabular}

Abbreviations: NA, not available; NT, not tested. ${ }^{\text {aHemolytic activity is the concentration required }}$ to provoke $10 \%$ hemolysis.

bSafety factor was calculated as the concentration inducing 10\% hemolysis over MIC against

A. niger.

'Positive controls.

against $A$. niger in which they are effectively equipotent. This difference suggests that the saturated sorbyl side chain is important for the biological activity of compound $\mathbf{1}$ only in mammalian cells. This interesting observation may not only provide clues as to mechanism of action of this class of agents, it also suggests that compound $\mathbf{5}$ may be a potential candidate for development as an antifungal, as it may not elicit substantial negative effects in normal human cells. This hypothesis was supported by the relatively high safety factor of compound $\mathbf{5}$ (as well as $\mathbf{1}$ ) with regards to hemolysis of sheep red blood cells. In addition to compounds $\mathbf{1}$ and $\mathbf{5}$, compound 3 also showed selective potency against $A$. niger, with a similarly low toxicity toward sheep red blood cells in vitro but a lower safety factor (that is, higher MIC).

The discovery of strong, narrow-spectrum anti- $A$. niger activity underscores the utility of subjecting natural products to as wide a screen as possible to detect biological activity. Since Aspergillus species are highly invasive to human beings and continue to present safety challenges for agricultural products and food, the exploration of novel structures for potential application in these settings is a high priority. ${ }^{19-21}$ The exceptional potency and apparent selectivity of several of the compounds isolated here strongly supports further exploration of this class of secondary metabolites.

\section{METHODS}

\section{General}

UV spectra were obtained using a Varian Cary 100 Bio UV-Vis spectrophotometer (Varian, Walnut Creek, CA, USA). NMR data were collected using either a JEOL ECA-500 NMR spectrometer operating at $500 \mathrm{MHz}$ for ${ }^{1} \mathrm{H}$ and $125 \mathrm{MHz}$ for ${ }^{13} \mathrm{C}$, or a JEOL ECS-400 NMR spectrometer operating at $400 \mathrm{MHz}$ for ${ }^{1} \mathrm{H}$ and $100 \mathrm{MHz}$ for ${ }^{13} \mathrm{C}$, and equipped with a high-sensitivity JEOL Royal probe and a 24-slot autosampler (both from JEOL, Tokyo, Japan), or an Agilent $700 \mathrm{MHz}$ NMR spectrometer (Agilent Technologies, Inc., Santa Clara, CA, USA), equipped with a cryoprope, operating at $700 \mathrm{MHz}$ for ${ }^{1} \mathrm{H}$ and $175 \mathrm{MHz}$ for ${ }^{13} \mathrm{C}$. Residual solvent signals were utilized for referencing. High resolution mass spectra (HR-MS) were obtained using a Thermo LTQ Orbitrap XL mass spectrometer equipped with an ESI source (Thermo Fisher Scientific, San Jose, CA, USA). A Waters Acquity UPLC system (Waters, Milford, MA, USA) utilizing a Waters $\mathrm{BEH}_{18}$ column $(1.7 \mu \mathrm{m} ; 50 \times 2.1 \mathrm{~mm})$ was used to check the purity of the isolated compounds with data collected and analyzed using Empower software (Waters Corp., Milford, MA, USA). Phenomenex Gemini-NX $\mathrm{C}_{18}$ analytical $(5 \mu \mathrm{m} ; 250 \times 4.6 \mathrm{~mm})$, preparative $(5 \mu \mathrm{m}$; $250 \times 21.2 \mathrm{~mm}$ ) and semipreparative $(5 \mu \mathrm{m} ; 250 \times 10.0 \mathrm{~mm})$ columns (all from Phenomenex, Torrance, CA, USA), and a YMC ODS-A analytical $(5 \mu \mathrm{m}$; $150 \times 4.6 \mathrm{~mm})$, preparative $(5 \mu \mathrm{m} ; 250 \times 20 \mathrm{~mm})$ and semipreparative $(5 \mu \mathrm{m}$; $250 \times 10.0 \mathrm{~mm}$ ) columns (all from YMC America, Allentown, PA, USA) were used on a Varian Prostar HPLC system equipped with ProStar 210 pumps and a Prostar 335 photodiode array detector, with data collected and analyzed using Galaxie Chromatography Workstation software (version 1.9.3.2, Varian). Flash chromatography was conducted on a Teledyne ISCO CombiFlash Rf using Silica Gold columns and monitored by UV and evaporative light-scattering detectors (both from Teledyne Isco, Lincoln, NE, USA).

\section{Fungal strain isolation and identification}

Mycosynthetix fungal strain MSX51631 was collected in 1990 from Cobb County, GA, USA. Molecular techniques were used to identify the strain by sequencing the nuclear internal transcribed spacers and intervening $5.8 \mathrm{~S}$ gene $^{22}$ along with the D1/D2 regions of the adjacent nuclear ribosomal large subunit. ${ }^{23,24}$ DNA extraction, PCR amplification, sequencing and phylogenetic analyses were conducted as described previously., 2,3,25-27 The ITS region was used for species-level identification using the pairwise sequence alignment option on the Fungal Barcoding webpage (http://www.fungalbarcoding.org/). ${ }^{24}$ This function allows performing online alignment between an input (query) sequence and the available sequences in the database, which comprise different curated global fungal databases, including, Q-bank Fungi database (http://www. q-bank.eu/fungi/); CBS-KNAW Fungal Biodiversity Centre (http://www.cbs. knaw.nl/Collections); Molecular Mycology Research Laboratory (http://www. mycologylab.org/); Portuguese Yeast Culture Collection (http://pycc.bio-aware. $\mathrm{com} /$ ) and NCBI GenBank. The search returns the best-matching pairwise (local) or global alignments of two query sequences. Identifications were performed in a monophasic way in which sequences were compared to produce a global similarity or probability coefficient between the unknown sequence and the reference sequence database (http://www.fungalbarcoding.org/). Based on the results of the pairwise sequence alignment, the closest genus and species that matched the ITS sequence of the strain MSX51631 were representatives 
of S. album (isotype sequence; CBS 372.65; identities $=482 / 485(99.3 \%)$, gaps $=0$ ), the other closest matches included those of Ascomycota sp. olrim 237 (AY787735; identities=470/470 (100\%), gaps=0), Ascomycota sp. olrim349 $($ HM036638; identities $=454 / 454(100 \%)$, gaps $=0)$. Pairwise sequence alignment was also performed with combined internal transcribed spacer-large subunit (ITS-LSU) region, which suggested that the closest match of the query sequence was $S$. album (isotype sequence; CBS 372.65; identities $=927 / 942$ $(98 \%)$, gaps $=6(0.7 \%)$.

A combined ITS-LSU rDNA complete linkage tree was generated using pairwise sequence alignment search on the Fungal Barcoding webpage (Supplementary Figure S13). Therefore, the strain MSX51631 was identified as having affinities to S. album L. Beyer \& Klingström. (Helotiales, Leotiomycetidae, Leotiomycetes, Pezizomycotina and Ascomycota). The combined ITS-LSU sequence was deposited in the GenBank (accession no. KJ772505).

\section{Fermentation, extraction and isolation}

Storage conditions, fermentation and extraction procedure of the fungal strain MSX51631 were as described previously. ${ }^{3,5,28}$ In brief, cultures of strain MSX51631 were grown in 2.8-1 Fernbach flasks (Corning, Corning, NY, USA) containing $150 \mathrm{~g}$ rice and $300 \mathrm{ml} \mathrm{H}_{2} \mathrm{O}$. A seed culture grown in YESD medium was used as an inoculum. Following incubation at $22^{\circ} \mathrm{C}$ for 14 days, the solid culture was extracted by adding a $500 \mathrm{ml}$ mixture of 1:1 $\mathrm{MeOH}-$ $\mathrm{CHCl}_{3}$. The culture was cut into small pieces using a spatula and shaken for about $16 \mathrm{~h}$ at $\sim 125$ r.p.m. at room temperature (rt), followed by vacuum filtration. The remaining residues were washed with $100 \mathrm{ml}$ of 1:1 $\mathrm{MeOH}-\mathrm{CHCl}_{3}$. To the filtrate, $900 \mathrm{ml} \mathrm{CHCl}_{3}$ and $1500 \mathrm{ml} \mathrm{H}_{2} \mathrm{O}$ were added; the mixture was stirred for $30 \mathrm{~min}$ and then transferred into a separatory funnel. The bottom layer was drawn off and evaporated to dryness. The dried organic extract was re-constituted in $100 \mathrm{ml}$ of $1: 1 \mathrm{MeOH}-\mathrm{CH}_{3} \mathrm{CN}$ and $100 \mathrm{ml}$ of hexanes. The biphasic solution was shaken vigorously and then transferred to a separatory funnel. The $\mathrm{MeOH}-\mathrm{CH}_{3} \mathrm{CN}$ layer was drawn off and evaporated to dryness under vacuum. The defatted material $(\sim 750 \mathrm{mg})$ was dissolved in a mixture of $\mathrm{CHCl}_{3}-\mathrm{MeOH}$, adsorbed onto Celite 545 and fractionated via flash chromatography using a gradient solvent system of hexane- $\mathrm{CHCl}_{3}-\mathrm{MeOH}$ at a $30 \mathrm{ml} \mathrm{min}^{-1}$ flow rate and 61.0 column volumes over $34.1 \mathrm{~min}$ to afford five fractions. Fraction $2(\sim 315.97 \mathrm{mg})$ was subjected to preparative reversed-phase HPLC over a Phenomenex Gemini-NX $\mathrm{C}_{18}$ preparative column using a gradient system of 50:50 to 70:30 over $50 \mathrm{~min}$ to $100: 00$ of $\mathrm{CH}_{3} \mathrm{CN}-\mathrm{H}_{2} \mathrm{O}$ (acidified with $0.1 \%$ formic acid) at a flow rate of $21 \mathrm{ml} \mathrm{min}^{-1}$ to yield thirteenth sub-fractions. Sub-fractions 2 and 7 yielded compounds 11 $(0.46 \mathrm{mg})$ and $3(0.55 \mathrm{mg})$, which eluted at $\sim 6.5$ and $\sim 27.5 \mathrm{~min}$, respectively. Sub-fractions $8-11$ were subjected to further purifications. Sub-fraction 8 (3.23 mg) was subjected to semipreparative HPLC purification over a Phenomenex Gemini-NX $\mathrm{C}_{18}$ column using a gradient system of 50:50 to 60:40 of $\mathrm{CH}_{3} \mathrm{CN}-\mathrm{H}_{2} \mathrm{O}$ (acidified with $0.1 \%$ formic acid) over $15 \mathrm{~min}$ at a flow rate of $4.72 \mathrm{ml} \mathrm{min}^{-1}$ to yield compounds $2(0.75 \mathrm{mg})$ and $7(1.65 \mathrm{mg})$, which eluted at $\sim 8.2$ and $\sim 10.5 \mathrm{~min}$, respectively. Sub-fraction $9(9.14 \mathrm{mg})$ was subjected to semipreparative HPLC purification using a Phenomenex Gemini-NX $\mathrm{C}_{18}$ and a gradient system of 70:30 to 80:20 of $\mathrm{CH}_{3} \mathrm{OH}-\mathrm{H}_{2} \mathrm{O}$ (acidified with $0.1 \%$ formic acid) over $20 \mathrm{~min}$ at a flow rate of $4.72 \mathrm{ml} \mathrm{min}^{-1}$ to yield compound 1 $(3.10 \mathrm{mg})$ that eluted at $\sim 12.5 \mathrm{~min}$. Sub-fraction $10(14.2 \mathrm{mg})$ was subjected to preparative HPLC purification using a YMC ODS-A column and an isocratic solvent system of $60: 40$ of $\mathrm{CH}_{3} \mathrm{OH}-\mathrm{H}_{2} \mathrm{O}$ (acidified with $0.1 \%$ formic acid) at a flow rate of $15 \mathrm{ml} \mathrm{min}^{-1}$ to yield compounds $1(5.21 \mathrm{mg}), 5(4.16 \mathrm{mg})$ and $\mathbf{6}$ $(1.83 \mathrm{mg})$, which eluted at $\sim 80.2, \sim 91.5$ and $\sim 106.3 \mathrm{~min}$, respectively. Subfraction $11(146.52 \mathrm{mg})$ was subjected to preparative HPLC purification using a Phenomenex Gemini-NX $\mathrm{C}_{18}$ and a gradient system of 60:40 to 100:00 of $\mathrm{CH}_{3} \mathrm{CN}-\mathrm{H}_{2} \mathrm{O}$ (acidified with $0.1 \%$ formic acid) over $30 \mathrm{~min}$ at a flow rate of $21.24 \mathrm{ml} \mathrm{min}^{-1}$ to yield compounds $1(3.33 \mathrm{mg})$ and $4(3.10 \mathrm{mg})$, which eluted at $\sim 11.0$ and $\sim 16.3 \mathrm{~min}$, respectively. To obtain purity over $95 \%$ as measured by UPLC, compounds $\mathbf{5}$ and $\mathbf{6}$ were further purified using semipreparative reversed-phase HPLC.

Another two large-scale cultures of MSX51631 were extracted, combined and fractionated as described above. The $\mathrm{MeOH}-\mathrm{CH}_{3} \mathrm{CN}$ fraction $(1.77 \mathrm{~g}$ ) was subjected to fractionation using flash chromatography and a gradient solvent system of hexane- $\mathrm{CHCl}_{3}-\mathrm{MeOH}$ at a $40 \mathrm{ml} \mathrm{min}^{-1}$ flow rate and 53.3 column volumes over $63.9 \mathrm{~min}$ to afford four fractions. Fraction 2 ( $868.95 \mathrm{mg})$ was subjected to extensive purifications using preparative and semipreparative reversed-phase HPLC and yielded additional amounts of compounds 1-7, which were isolated from the first processed large scale of MSX51631, along with compounds 8 (2.47 mg), 9 (5.54 mg) and 10 (7.91 mg).

\section{Scalbucillin A (2)}

Compound 2 was isolated as a yellow solid $(1.77 \mathrm{mg}) ; \mathrm{UV}(\mathrm{MeOH}) \lambda_{\max }(\log \varepsilon)$ 349 (3.57), 309 (3.64), 247 (3.51), 222 (3.47) nm; ${ }^{1} \mathrm{H}$ NMR $\left(\mathrm{CDCl}_{3}, 700 \mathrm{MHz}\right)$ and ${ }^{13} \mathrm{C}$ NMR $\left(\mathrm{CDCl}_{3}, 175 \mathrm{MHz}\right)$, Tables 1 and 2, and Supplementary Figure S3; HR-ESIMS m/z $263.0910[\mathrm{M}+\mathrm{H}]^{+}$(calcd for $\mathrm{C}_{14} \mathrm{H}_{15} \mathrm{O}_{5} 263.0914$ ).

\section{Scalbucillin B (3)}

Compound 3 was isolated as a yellow solid $(1.10 \mathrm{mg}) ; \mathrm{UV}(\mathrm{MeOH}) \lambda_{\max }(\log \varepsilon)$ 349 (3.22), 310 (3.31), $231(3.22) \mathrm{nm} ;{ }^{1} \mathrm{H}$ NMR $\left(\mathrm{CDCl}_{3}, 700 \mathrm{MHz}\right)$ and ${ }^{13} \mathrm{C}$ NMR $\left(\mathrm{CDCl}_{3}, 175 \mathrm{MHz}\right)$, Tables 1 and 2 and Supplementary Figure S4; HR-ESIMS $m / z 249.1115[\mathrm{M}+\mathrm{H}]^{+}\left(\right.$calcd for $\left.\mathrm{C}_{14} \mathrm{H}_{17} \mathrm{O}_{4} 249.1121\right)$.

\section{Scalbucillin C (6)}

Compound 6 was isolated as a white solid (9.97 mg); UV (MeOH) $\lambda_{\max }(\log \varepsilon)$ 312 (3.56), 275 (3.71), $246(3.71) \mathrm{nm} ;{ }^{1} \mathrm{H} \mathrm{NMR}\left(\mathrm{CDCl}_{3}, 500 \mathrm{MHz}\right)$ and ${ }^{13} \mathrm{C}$ NMR $\left(\mathrm{CDCl}_{3}, 125 \mathrm{MHz}\right)$, Tables 1 and 2, and Supplementary Figure S7; HR-ESIMS $m / z 279.1221[\mathrm{M}+\mathrm{H}]^{+}$(calcd for $\mathrm{C}_{15} \mathrm{H}_{19} \mathrm{O}_{5} 279.1227$ ).

\section{Scalbucillin D (8)}

Compound 8 was isolated as a white solid $(2.47 \mathrm{mg}) ; \mathrm{UV}(\mathrm{MeOH}) \lambda_{\max }(\log \varepsilon)$ 324 (3.61), 275 (3.65), 237 (3.62) nm; ${ }^{1} \mathrm{H} \mathrm{NMR}\left(\mathrm{CDCl}_{3}, 500 \mathrm{MHz}\right)$ and ${ }^{13} \mathrm{C}$ NMR $\left(\mathrm{CDCl}_{3}, 125 \mathrm{MHz}\right)$, Tables 1 and 2, and Supplementary Figure S9; HR-ESIMS m/z $235.1323[\mathrm{M}+\mathrm{H}]^{+}\left(\right.$calcd for $\mathrm{C}_{14} \mathrm{H}_{18} \mathrm{O}_{3} 235.1329$ ).

\section{Cytotoxicity assays}

Compounds (1-11) were tested against the MDA-MB- $435^{29}$ human melanoma (HTB-129, American Type Culture Collection (ATCC; Manassas, VA, USA) and the SW- $620^{30}$ human colorectal adenocarcinoma (CCL-227, ATCC) cell lines, both were purchased from the ATCC, as described previously. ${ }^{31}$ In brief, the lines were propagated at $37^{\circ} \mathrm{C}$ in an atmosphere of $5 \% \mathrm{CO}_{2}$ in air in RPMI 1640 supplemented with fetal bovine serum (10\%), penicillin (100 units $\mathrm{ml}^{-1}$ ) and streptomycin $\left(100 \mu \mathrm{g} \mathrm{ml}^{-1}\right)$. Cells in log-phase growth were harvested by trypsinization and washed twice with PBS to remove all traces of enzyme. A total of 5000 cells were seeded per well of a 96-well clear, flat-bottom plate (Microtest 96, Falcon, Swedesboro, NJ, USA) and incubated overnight $\left(37^{\circ} \mathrm{C}\right.$ in $5 \% \mathrm{CO}_{2}$ ). Samples dissolved in DMSO were then diluted and added to the appropriate wells (concentrations: 25, 5, 1, 0.2 and $0.04 \mu \mathrm{g} \mathrm{ml}^{-1}$; total volume: $100 \mu$ l; DMSO: $0.5 \%)$. The cells were incubated in the presence of test substance for $72 \mathrm{~h}$ at $37^{\circ} \mathrm{C}$ and evaluated for viability with a commercial absorbance assay (CellTiter 96 AQueous One Solution Cell Proliferation Assay, Promega, Madison, WI, USA). Activity was expressed by molarity relative to the negative (solvent) control. The positive control was vinblastine tested at $1 \mathrm{~nm}$ in MDA-MB-435 cells (48\% viability) and $10 \mathrm{~nm}$ in SW-620 cells (30\% viablility).

Compounds $\mathbf{1}$ and $\mathbf{5}$ were also tested against the B-lymphocytic cell line OSU-CLL ${ }^{7}$ using CellTiter 96 reagents according to the manufacturer's instructions (Promega). The $48-\mathrm{h} \mathrm{IC}_{50}$ of compound 1 was calculated using Prism software (GraphPad, La Jolla, CA, USA).

\section{Antimicrobial assay}

The antimicrobial activity of compounds $(1-11)$ against a panel of bacteria and fungi were measured as described previously. ${ }^{31}$ In brief, strains of Escherichia coli strain C (ATCC 13706), Staphylococcus aureus (ATCC 6538) and Mycobacterium smegmatis (ATCC 607) were obtained from the ATCC. Saccharomyces cerevisiae, Candida albicans, Cryptococcus neoformans, A. niger and Micrococcus luteus strains were obtained from the Virginia Tech Microbiology teaching culture collection. Colonies of E. coli, S. aureus, M. luteus, S. cerevisiae, C. albicans and C. neoformans were grown on 1/10-strength Brain Heart Infusion Broth (BBL Microbiology Systems, Cockeysville, MD, USA) containing $0.2 \%(\mathrm{w} / \mathrm{v})$ sucrose $(\mathrm{BHIB}+\mathrm{S})$ and $1.5 \%(\mathrm{w} / \mathrm{v})$ agar. M. smegmatis 
was grown on Middlebrook 7H10 agar (BBL Microbiology Systems) and A. niger on potato dextrose agar (PDA; BBL Microbiology Systems). Streaked plates were incubated at $37^{\circ} \mathrm{C}$ for 3-7 days, except for that of $A$. niger, which was incubated in the dark at $30^{\circ} \mathrm{C}$. A single colony for each microbe, except $A$. niger, was used to inoculate $5 \mathrm{ml}$ of 1/10-strength BHIB+S (E. coli, M. luteus and S. aureus), Middlebrook 7H9 broth (M. smegmatis) or yeast extract peptone maltose broth (S. cerevisiae, C. albicans and C. neoformans) and incubated at $37^{\circ} \mathrm{C}$ (S. cerevisiae and $M$. luteus at $30^{\circ} \mathrm{C}$ ) for $4-7$ days. After growth, the resulting broth cultures were diluted with buffered saline gelatin (gelatin $(0.1$ $\left.\left.\mathrm{gl}^{-1}\right), \mathrm{NaCl}\left(8.5 \mathrm{gl}^{-1}\right), \mathrm{KH}_{2} \mathrm{PO}_{4}\left(0.3 \mathrm{gl}^{-1}\right), \mathrm{Na}_{2} \mathrm{HPO}_{4}\left(0.6 \mathrm{gl}^{-1}\right)\right)$ to equal the turbidity of a No. 1 McFarland standard. Broth cultures were streaked on plate count agar (BBL Microbiology Systems) and incubated for 3-4 days at $37^{\circ} \mathrm{C}$, so as to check for viability and contamination. Plates for M. luteus and S. cerevisiae were grown at $30^{\circ} \mathrm{C}$. Spores of $A$. niger were scraped from the surface of the PDA and suspended in $5 \mathrm{ml}$ of 1/10-strength BHIB+S, and that suspension was transferred to a sterile test tube. The turbidity was adjusted to be equivalent to that of a No. 1 McFarland standard by dilution with buffered saline gelatin. Those spore suspensions were streaked on PDA and incubated at $37^{\circ} \mathrm{C}$ for 3-4 days, so as to confirm viability and lack of contamination.

The MICs of the isolated compounds were measured by broth microdilution in 96-well microtitre plates. A twofold dilution series of the compounds was prepared in 96-well microtitre plates in a $50 \mu \mathrm{l}$ volume of $1 / 10$-strength $\mathrm{BHIB}+\mathrm{S}$, and the dilution series was inoculated with $50 \mu \mathrm{l}$ of each cell suspension. The resulting inoculated dilution series were incubated at either 30 or $37^{\circ} \mathrm{C}$ (same as growth temperature), and growth, as noted by turbidity, was scored visually and recorded on the fourth day. MIC of each compound was measured in triplicate and was defined as the lowest concentration of drug resulting in absence of turbidity compared with the drug-free control.

\section{Hemolytic assay}

Hemolytic activity of compounds $\mathbf{1}, \mathbf{3}$ and $\mathbf{5}$ was measured against sheep red blood cells as described elsewhere. ${ }^{32}$

\section{ACKNOWLEDGEMENTS}

This research was supported by program project grant P01 CA125066 from the National Cancer Institute/National Institutes of Health, Bethesda, MD, USA. The high-resolution MS data were acquired at the Triad Mass Spectrometry Laboratory at the University of North Carolina at Greensboro. Sequence data was generated at the Mycology laboratory of Dr Andrew N Miller, Illinois Natural History Survey, University of Illinois at Urbana-Champaign.

1 El-Elimat, T. et al. High-resolution MS, MS/MS, and UV database of fungal secondary metabolites as a dereplication protocol for bioactive natural products. J. Nat. Prod. 76 1709-1716 (2013).

2 El-Elimat, T. et al. Waol A, trans-dihydrowaol A, and cis-dihydrowaol A: polyketide-derived gamma-lactones from a Volutella species. Tetrahedron Lett. 54 4300-4302 (2013)

3 El-Elimat, T. et al. Benzoquinones and terphenyl compounds as phosphodiesterase-4B inhibitors from a fungus of the order Chaetothyriales (MSX 47445). J. Nat. Prod. 76, 382-387 (2013)

4 El-Elimat, T. et al. Chemical diversity of metabolites from fungi, cyanobacteria, and plants relative to FDA-approved anticancer agents. ACS Med. Chem. Lett. 3 645-649 (2012).

5 Figueroa, M. et al. Cytotoxic epipolythiodioxopiperazine alkaloids from filamentous fung of the Bionectriaceae. J. Antibiot. 65, 559-564 (2012).
6 Sy-Cordero, A. A., Pearce, C. J., Oberlies, N. H. Revisiting the enniatins: A review of their isolation, biosynthesis, structure determination, and biological activities. J. Antibiot. 65, 541-549 (2012).

7 Hertlein, E. et al. Characterization of a new chronic lymphocytic leukemia cell line for mechanistic in vitro and in vivo studies relevant to disease. PLOS ONE 8 e76607 (2013)

8 Harned, A. M., Volp, K. A. The sorbicillinoid family of natural products: Isolation, biosynthesis, and synthetic studies. Nat. Prod. Rep. 28, 1790-1810 (2011).

9 Geigert, J., Stermitz, F. R., Schroeder, H. A. Two new natural substituted hexenophenones from fungus Scytalidium. Tetrahedron 29, 2343-2345 (1973).

10 Reátegui, R. F., Wicklow, D. T., Gloer, J. B. Phaeofurans and sorbicillin analogues from a fungicolous Phaeoacremonium species (NRRL 32148). J. Nat. Prod. 69, 113-117 (2006).

11 Optiz, L., Hänsel, R. Phthalide aus Helichrysum italicurn. Arch. Pharm. 304 228-230 (1971).

12 Yoshikawa, K et al. Novel phthalide compounds from Sparassis crispa (Hanabiratake), hanabiratakelide A-C, exhibiting anti-cancer related activity. Biol. Pharm. Bull. 33, 1355-1359 (2010).

13 Nakano, Y., Takashima, T. Extractives of Albizzia julibrissin Durazz. heartwood. Mokuzai Gakkaishi 21, 577-580 (1975).

14 dos Santos, E. D., Beatriz, A., de Lima, D. P., Marques, M. R., Leite, C. B. Synthesis of resorcinolic lipids bearing structural similarities to cytosporone A. Quim. Nova 32 1856-1859 (2009).

15 Evidente, A. et al. Regiolone and isosclerone, two enantiomeric phytotoxic naphthalenone pentaketides: computational assignment of absolute configuration and its relationship with phytotoxic activity. Eur. J. Org. Chem. 2011 , 5564-5570 (2011)

16 Stermitz, F. R., Adamovics, J. A., Geigert, J. Synthesis and photoreactions of sorbophenones: A photochemical synthesis of flavone. Tetrahedron 31 1593-1595 (1975)

17 Ichihashi, K., Osawa, T., Toyokuni, S., Uchida, K. Endogenous formation of protein adducts with carcinogenic aldehydes: Implications for oxidative stress. J. Biol. Chem. 276, 23903-23913 (2001) .

18 Wang M. et al. A Schiff base is a major DNA adduct of crotonaldehyde. Chem. Res Toxicol. 14, 423-430 (2001).

19 Klich, M. A. Health effects of Aspergillus in food and air. Toxicol. Ind. Health 25 657-667 (2009)

20 Perrone, G. et al. Biodiversity of Aspergillus species in some important agricultural products. Stud. Mycol. 59, 53-66 (2007)

21 Lass-Florl, C., Roilides, E., Loffler, J., Wilflingseder, D., Romani, L. Minireview: host defence in invasive aspergillosis. Mycoses 2013; 56, 403-413.

22 Schoch, C. L. et al. Nuclear ribosomal internal transcribed spacer (ITS) region as a universal DNA barcode marker for fungi. Proc. Natl Acad. Sci. USA 109 6241-6246 (2012)

23 Liu, K. L., Porras-Alfaro, A., Kuske, C. R., Eichorst, S. A., Xie, G. Accurate, rapid taxonomic classification of fungal large-subunit rRNA genes. Appl. Environ. Microbiol. 78, 1523-1533 (2012).

24 Eberhardt, U. in DNA Barcodes. Methods in Molecular Biology (eds Kress, W. J., Erickson, D. L.) pp183-205 (Humana Press, New York, 2012).

25 Figueroa, M. et al. Peptaibols, tetramic acid derivatives, isocoumarins, and sesquiterpenes from a Bionectria sp (MSX 47401). J. Nat. Prod. 76 1007-1015 (2013)

26 Raja, H. A. et al. Lindgomyces angustiascus, (Lindgomycetaceae, Pleosporales, Dothideomycetes), a new lignicolous species from freshwater habitats in the USA Mycoscience 54, 353-361 (2013).

27 Raja, H. A. et al. Freshwater Ascomycetes: Minutisphaera (Dothideomycetes) revisited, including one new species from Japan. Mycologia 105, 959-976 (2013)

28 Ayers, S. et al. Resorcylic acid lactones with cytotoxic and NF-kB inhibitory activities and their structure-activity relationships. J. Nat. Prod. 74 1126-1131 (2011)

29 Rae, J., Creighton, C., Meck, J., Haddad, B., Johnson, M. MDA-MB-435 cells are derived from M14 Melanoma cells-a loss for breast cancer, but a boon for melanoma research. Breast Cancer Res. Treat. 104, 13-19 (2007) .

30 Leibovitz, A. et al. Classification of human colorectal adenocarcinoma cell lines. Cancer Res. 36, 4562-4569 (1976).

31 Alali, F. Q. et al. Bioactive withanolides from Withania obtusifolia. Phytochem. Lett. 9, 96-101 (2014)

32 Lin, Z. J. et al. Burkholdines from Burkholderia ambifaria: Antifungal agents and possible virulence factors. J. Nat. Prod. 75, 1518-1523 (2012).

Supplementary Information accompanies the paper on The Journal of Antibiotics website (http://www.nature.com/ja) 